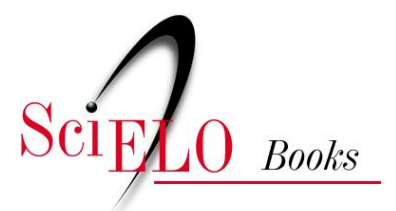

\title{
Três séculos depois
}

\author{
Capistrano de Abreu
}

\section{SciELO Books / SciELO Livros / SciELO Libros}

ABREU, C. Três séculos depois. In: Capitulos da história colonial [online]. Rio de Janeiro: Centro Edelstein de Pesquisa Social, 2009. pp. 173-195. ISBN: 978-85-7982-071-7.

https://doi.org/10.7476/9788579820717.0011.

\section{(2) poviuc}

This work is free of known copyright restrictions. http://creativecommons.org/publicdomain/mark/1.0/

Este trabalho está livre de restrições de direito de autor e/ou de direitos conexos conhecidas.

http://creativecommons.org/publicdomain/mark/1.0/

Esta obra está libre de restricciones conocidas de derechos autorales. http://creativecommons.org/publicdomain/mark/1.0/ 


\section{TRÊS SÉCULOS DEPOIS}

Três séculos depois do descobrimento os habitantes do Brasil exprimiam-se por sete algarismos. Repartidos na superfície reclamada como sua pela metrópole, tocavam dois ou três quilômetros quadrados a cada indivíduo.

A população ocupava a marinha desde Marajó até o Chuí, e uma e outra margem do Amazonas desde a foz de Tabatinga ao Javari. Nos tributários desta bacia os povoados, de preferência estabelecidos nos caudais de água preta, paravam a pouca distância da barra, exceto no rio Negro, onde preocupações de limites tinham requintado a expansão natural, no Madeira, Tapajós e Tocantins, ligados a Mato Grosso e Goiás. Desde o Piauí à linha singela do litoral correspondiam uma ou mais linhas interiores de povoamento nas beiras dos rios e nos chapadões do Parnaíba, do S. Francisco, do Paraná e regiões intermédias. Estas linhas, interrompidas a cada instante, melhor se diriam pontos indicando um traçado a realizar.

Observando a distribuição geográfica dos povoadores notavam-se duas correntes fáceis de distinguir. A corrente espontânea do povoamento tendia à continuidade e procurava a periferia a Oeste, ao Norte e ao Sul. A corrente voluntária, determinada por ação governativa, ambição de territórios ou vantagens estratégicas, aparecia salteada e desconexa, e começando da periferia procurava rumos opostos. Nas terras auríferas a ocorrência irregular dos minérios trouxe primitivamente a desconexão dos núcleos, mais tarde corrigida onde foi possível.

A maioria constava de mestiços; a mestiçagem variava de composição conforme as localidades. Na Amazônia prevalecia o elemento indígena, abundavam mamalucos, rareavam os mulatos. Na zona pastoril existiam poucos negros e foram assimilados muitos índios. À beira-mar e nas comarcas dos metais sobressaía o negro, com todos os derivados deste radical. Ao Sul dos trópicos elevava-se a porcentagem dos brancos. Das três raças irredutíveis, oriunda cada qual de um continente e compelidas à convivência forçada, eram os africanos a que maior número de representantes puros possuía, em consequência das levas anualmente fornecidas pelo tráfico dos negreiros. 
Na baixada amazônica o predomínio da água e da mata restringiam as ocupações agrícola e pastoril. Lavoura existia apenas nas proximidades dos povoados maiores, limitada à cana, ao café, a poucos cereais e à mandioca: esta desfazia-se em farinha d'água, mais resistente à umidade; o tucupi ou manipuera dava um molho apreciado; cru servia também para apanhar aves. O gado vacum criado na ilha do Marajó, perto do Paru, em Obidos, no Tapajós, nos campos do rio Branco, não chegava para o consumo interno. De gado cavalar ainda menos se curava: as embarcações, desde a montaria, verdadeira sucedânea do cavalo, como o nome está indicando, até as grandes canoas, arqueando centenas de arrobas, e durante parte do ano impelidas rio arriba pelos ventos gerais, eram o quase exclusivo meio de transporte.

O povo alimentava-se de peixe fresco, pegado diàriamente pelos múltiplos e engenhosos processos recebidos dos indígenas, ou salgado, como o pirarucu, a tainha e o peixe-boi; de tartaruga, mais abundante à medida que se caminhava para Oeste, ou porque assim estivesse distribuída originariamente, ou por se não ter adiantado tanto por aquelas bandas a obra de devastação. Verdadeira vaca amazônica, gado do rio como a chamavam, podia-se guardar às centenas em currais, e fornecia manteiga; a gema do ovo de uma espécie tomava-se com café, como leite. Sua manteiga, além, de condimento usual, fornecia iluminação; o casco, sem brilho e por isso imprestável para obras delicadas, empregava-se como vasilha.

A extração de produtos florestais, cacau, salsa, piaçaba, cravo, ocupava a maioria da população masculina em certas quadras do ano, marcadas pelas enchentes e vasantes do rio-mar, durante as quais as aldeias ficavam reduzidas a velhos, meninos e mulheres. Estas fabricavam louça, pintavam coités, não raro reveladoras de talento artístico, fiavam e teciam. A seringueira, já conhecida e utilizada, entrava apenas no fabrico de objetos caseiros, como o que lhe deu o nome, ou no tornar impermeáveis botas e tecidos. Nem de longe se poderia ainda prever a importância que lhe adveio depois de descobertos os modernos processos de manipulação.

"Nenhuns [cuidados] parecem ter comumente no estado", escrevia Fr. João de São José em tempo de Pombal, e continuava a ser verdade: havendo rede, farinha e cachimbo, está em termos. A frugalidade da mesa pode passar se fosse coerente a de beber; e quanto ao mais é expressão vulgar a da seguinte endecha ou trova:
Vida do Pará,

Vida de descanso;

Comer de arremesso,

Dormir de balanço.

Da bacia amazônica passando à zona pastoril, notava-se logo a falta de mata e a escassez de água. A mata aparece apenas às margens das correntes mais caudalosas, em algumas baixadas úmidas, em serras elevadas de mil metros mais ou menos de altitude. A água, excetuando alguns rios permanentes, limitava-se a ipueiras, olhos d'água, poços naturais, mais ou menos grandes e constantes; fora destes casos tem-se de procurá-lo no seio da terra, operação fácil nos álveos secos, em outros casos empresa árdua e até frustânea. Em geral não prima quanto ao gosto, em consequência da salinidade dos terrenos que a filtram. O caráter salino do solo, a abundância de pastos suculentos, os campos mimosos e agrestes, determinaram a multiplicação do gado vacum. Vivia solto o maior tempo. $\mathrm{Na}$ época da parição, as vacas eram recolhidas ao curral, por causa dos cuidados exigidos pelo bezerro, e também do leite, e mais tarde do queijo e do requeijão; pouco valia a manteiga, se merece este nome o esquisito produto guardado em botijas, que se aquecia para extrair o conteúdo.

O gado não se prendia ao descampado; internava-se pelas catingas e amontava. $\mathrm{O}$ vaqueiro corria-lhe ao encalço, e com uma vara de ferrão em alguns pontos, em outros pela simples apreensão do rabo, deitava a rês em terra e subjugava-a. "Quando o vaqueiro se aproxima o boi foge para o mato mais próximo", informa Koster;

segue-o o homem tão de perto quanto possível, a fim de aproveitar a aberta que o animal faz apartando os galhos, os quais se aproximam logo depois e retomam a sua posição antiga. Algumas vezes o boi passa sob o grosso e baixo galho de uma árvore grande; o cavaleiro passa igualmente por baixo do galho; para consegui-lo inclina-se tanto à direita que pode agarrar a silha com a mão esquerda; ao mesmo tempo prende-se com o calcanhar esquerdo à aba da sela; nesta posição, roçando quase em terra, de aguilhada em punho segue sem diminuir a andadura, endireitando-se novamente no assento desde que transpôs o obstáculo. Se pode alcançar o boi, mete-lhe o aguilhão na anca, e fazendo-o com jeito, derriba-o. Apeia então, liga as pernas do animal, ou passa-lhe uma das mãos por cima dos 
chifres, o que o segura do modo mais eficaz. Estes homens recebem muitas vezes ferimentos, mas raro é que ocasionem mortes.

A tradição popular celebrou alguns dos barbatões mais famosos, como o boi Espaço (espaço, isto é, de chifres espaçados, não espácio, como José de Alencar escreveu e outros têm repetido), o Surubim, o Rabicho da Geralda.

$\mathrm{Na}$ boca deste uma poesia publicada por Sílvio Romero põe as seguintes quadras:

\section{Foi uma carreira feia}

Para a serra da Chapada,

Quando eu cuidei era tarde,

Tinha o cabra na rabada.

Tinha adiante um pau caído,

$\mathrm{Na}$ descida de um riacho,

O cabra passou por riba.

O russo passou por baixo.

Apertei mais a carreira

Fui passar no boqueirão,

$\mathrm{O}$ russo rolou no fundo,

O cabra pulou no chão.

O gado cavalar dava bem no sertão, mas nunca se multiplicou tanto como o outro, por falta de forragem apropriada. Talvez isto, mais que a falta de cruzamento, explique a diminuição da estatura; em todo caso sua resistência ao trabalho é incomparável, a exiguidade do porte apropriava-o às corridas pelo cantigal. As viagens eram sempre interrompidas nas horas de maior calor; não se ferravam os cavalos, cujo casco rijo resistia às pederneiras sem estropeio. O gado muar quase, senão de todo, se desconhecia no começo. Havia poucas ovelhas e cabras: o desenvolvimento destas data dos últimos trinta anos, depois de reconhecida a superioridade de sua pele.
$\mathrm{Na}$ alimentação entrava naturalmente a carne, mas em quantidade menor do que se poderia supor. Uma rês tinha grande valor relativo, porque ficavam próximos consideráveis centros de consumo, como Bahia e Pernambuco. Além disso, dos sertões do Parnaíba e São Francisco e das ribeiras concabeçantes partiu o gado que abasteceu e inçou Minas Gerais, Goiás e indiretamente Mato Grosso; tal abastecimento encareceu ainda mais a mercadoria, desfalcando-a. Cumpre não esquecer a calamidade das secas. Assim consumia-se principalmente carne secada ao sol, ou a do gado miúdo, de preferência à de ovelha.

No começo nada se plantava, julgando o terreno estéril; mais tarde introduziu-se o feijão, o milho, a mandioca e até a cana. São ainda hoje três épocas alegres do ano sertanejo: a do milho verde, a da farinha e a da moagem. Do milho seco, quase exclusivamente reservado para os cavalos, só se utilizavam torrado ou feito pipoca, transformado no raro cuscus ou no insípido aluá. O milho verde, cozido ou assado, feito pamonha ou canjica (no sentido do Norte, muito diverso do Sul), o milho verde durante semanas tirava o gosto das outras comidas. A farinhada com a farinha mole, os beijus de coco ou de folha, as tapiocas, os grudes, etc., as cenas joviais da rapagem de mandioca, representavam dias de convivência e cordialidade. A moagem era a cana assada, a garapa, o alfenim, a rapadura, o mel de engenho.

Estas festas, exceto a do milho, provavelmente herdada dos indígenas, pressupunham a casa grande, isto é, proprietários abastados que residiam em suas terras e escravos que as cultivavam. Nas proximidades moravam agregados, livres e dedicados. Muitas vezes por motivos fúteis entre os donos de duas casas grandes irrompiam questões que podiam pôr em armas populações inteiras. São características as lutas de Montes e Feitosas no Ceará. Os inventos mecânicos, que no século dezoito revolucionaram a indústria dos tecidos, aumentando o consumo do algodão, levaram o plantio aos terrenos mais afastados, por onde difundiram o bemestar.

O dono da casa grande, como toda a população masculina, exceto quando viajava, andava de ceroula e camisa, geralmente com rosários, relíquias, orações cuidadosamente cosidas e escapulários ao pescoço. Nas ocasiões solenes, recebendo visitas, revestia-se de quimão, timão ou chambre. "Quando um brasileiro põe-se a usar um desses hábitos talares 
começa a se considerar personagem importante (gentleman) e com título portanto a muita consideração", informa Koster. A roupa caseira das mulheres constava de camisa e saia; o casebeque só apareceu mais tarde. As moças solteiras dormiam juntas num gineceu chamado camarinha. Não apareciam aos estranhos. Era comum verem-se os noivos pela primeira vez no dia do casamento. Entre as joias prezava-se sobretudo o colar: o número de varas de cordão possuído pela mulher indicava até certo ponto sua hierarquia. Até as alongadas brenhas penetravam os bufarinheiros levando ouros, fazendas, utensílios domésticos. Quando os objetos se permutavam em gado, alugavam gente para arrebanhá-lo, e podiam voltar com grande número de cabeças. O mesmo sucedia aos dizimeiros, e até a eclesiásticos ambulantes. Um fenômeno daquelas regiões, ainda hoje existentes, eram as feiras de gado ou de outros gêneros. Algumas feiras deram origem a povoados.

A zona criadeira começava um pouco acima da foz do São Francisco, acompanhava-lhe as margens a entestar com a fronteira de Minas Gerais, transpunha as vertentes do Tocantins e do Parnaíba, alcançava já enfraquecida o alto Itapicuru, compreendia as ribeiras de todos os rios de meia-água metidos entre a baía de Todos-os-Santos e a de Tutoia. A trechos se aproximava muito da beira-mar, de que em Ilhéus e Porto Seguro separavam-na a serra do Espinhaço e suas matas litorâneas. Em Pernambuco ocorria fato semelhante, porque como as ligações beiravam o rio de São Francisco, a maior ou menor distância, grande número de sertanejos achavam mais fácil e mais vantajoso comunicar-se com a Bahia, deixando deserta uma região intermédia, variável em comprimento e largura; o caminho entre Pajeú e Capibaribe, que regulou esta anomalia, data dos primeiros anos do século XIX.

Como vimos, pode-se chamar pernambucanos os sertões de fora, desde Paraíba até o Acaracu no Ceará; baianos os sertões de dentro, desde o rio S. Francisco até o sudoeste do Maranhão. Entre os sertanejos de um e outro grupo deve ter havido diferenças mais ou menos sensíveis. Talvez se venha a determiná-las um dia, quando forem divulgadas as relações dos missionários, corregedores, etc.; em todo caso as semelhanças entre os moradores de ambos os sertões avultam mais que entre quaisquer outros habitantes do Brasil.
Nas margens do rio S. Francisco encontraram-se baianos e pernambucanos com os paulistas. Ao Sul e ao ocidente pode-se determinar até certo ponto os limites das duas correntes opostas, marcando os lugares em que os altos deixam de ser preferidos para a habitação, mesmo quando não há perigo de ser inundado o terreno, e entram a funcionar os monjolos.

Predileção pelas baixas para as casas de vivenda, frequência de monjolo para pilar o milho seco, milho como alimentação habitual, sob as formas de canjica (no sentido do Sul), fubá e farinha fermentada antes da torrefação definitiva, carne de porco preferida à de boi indicam a presença de paulistas ou de seus descendentes. Como raiz de todas estas vergônteas aparece a falta de sal, que impedia o desenvolvimento rápido do gado vacum e ainda hoje não tempera o angu nem a canjica. O porco, apesar de enorme consumo interno, tornou-se mais tarde gênero de exportação, em toucinho e em pé.

Para o terreno acidentado provavam melhor os muares, mais sóbrios, mais resistentes, de passo mais seguro, importados de além Uruguai. A viagem, não partida como ao Norte, arrastava-se vagarosamente quase de sol a sol. As cavalgaduras eram ferradas; nos caminhos mais frequentados, junto às vendas que forneciam milho, havia ferradores, e seus serviços reclamavam a cada instante os terríveis caldeirões.

O ouro, passado o alborôto primitivo, quase só ocupava faiscadores. A mineração de ferro, aprendida de africanos, segundo informa Eschwege pouco deu de si pelo atraso dos processos e sobretudo pela ausência de lenha, devastada cruelmente. A agricultura, além de cereais comuns, encontrou a aplicação rendosa no algodão: o de Minas-Novas procurava-se muito pela excelente qualidade. A cultura do café começou relativamente tarde, depois de verificada a superioridade das regiões serranas sobre as de beira-mar, nas proximidades do Rio, e desde o começo revestiu os caracteres que conservou até o fim.

Perguntou Augusto de Saint-Hilaire a um seu compatriota, conhecedor da localidade, em que os fazendeiros gastavam o dinheiro:

Como vê, respondeu-lhe, não é em construir belas casas nem em mobiliá-las. Comem arroz e feijão; muito pouco lhes custa também o vestuário, tão pouco dispendem na educação de seus filhos, que se rebolcam na ignorância; são de todo estranhos aos prazeres da sociedade; mas é o café que lhes dá dinheiro, não se pode apanhar 
café senão com negros; é pois em comprar negros que gastam todos os seus rendimentos, e o aumento de sua fortuna serve muito mais para satisfazer-lhes a vaidade que para aumentar-lhes os gozos. Não têm luxos de habitação, nada apregoa sua riqueza. Mas é impossível que se ignore nas cercanias que têm tantos escravos, tantos pés de café; empertigam-se, comprazem-se consigo mesmo e vivem satisfeitos, não se distinguindo realmente dos pobres senão por uma vã nomeada que se estende a alguns tiros de espingarda de sua casa.

Esta instalação sumária e pobre apareceria nos lugares recentemente desbravados; nos de ocupação mais antiga notava-se espetáculo bem diferente.

Às fazendas apartadas falece todo o auxílio da grande sociedade, escreve Martius, entre Vila-Rica e a demarcação diamantina; cada fazendeiro rico é por isso obrigado a preparar os escravos para todas as necessidades da sua casa. Assim comumente acham-se numa casa todos os oficiais e a aviação para eles, como sapateiros, alfaiates, tecelões, serralheiros, ferreiros, pedreiros, oleiros, caçadores, mineiros, agricultores... À frente dos negócios está um feitor, mulato ou negro de confiança, e determina-se a ordem do dia como num convento. O dono faz ao mesmo tempo de regedor, juiz e médico em sua propriedade. Muitas vezes é um eclesiástico ou vem um clérigo da vizinhança celebrar em sua capela particular.

Como alguns frades figuraram nas primeiras desordens, a metrópole proibiu severamente a fundação de conventos nas três capitanias auríferas e, caso raro, nunca variou a tal respeito. Em tanto maior número apareceram os clérigos dos hábito de $\mathrm{S}$. Pedro, a princípio importados, ordenados mais tarde no ribeirão do Carmo, depois de criada a diocese de Mariana sob d. João V, por Benedito XIV.

Desde a nomeação do bispo de Mariana, d. Joaquim Borges de Figueiroa (1782), se tem conferido ordem a um sem número de sujeitos, sem necessidade e sem escolha. Tem-se visto alguns que, tendo aprendido ofícios mecânicos e servido de soldados pedestres, se acham hoje feitos sacerdotes. Tendo o doutor Francisco Xavier da Rua, governador que foi do bispado com procuração do dito bispo, ordenado os sacerdotes que eram precisos, não foi bastante para que o Dr. José Justino de Oliveira Gondim, que lhe sucedeu, deixasse de ordenar em menos de três anos cento e um pretendentes, dispensando sem necessidade em mulatismos e ilegitimidades. O Dr. Inácio
Correia de Sá, que sucedeu a este José Justino no governo do bispado, ordenou oitenta e quatro pretendentes em menos de sete meses e entre eles um que era devedor à fazenda real. XIX

Estas facilidades só começaram a desaparecer no correr do século

Junte-se a tal fartura de sacerdotes a abundância de irmandades, o gosto geral pela música, a proximidade dos povoados nos distritos em que primeiro se extraiu o metal amarelo, os numerosos vadios sustentados pela hospitalidade e indiferença indígenas, a falta de divertimentos públicos e se compreenderá a frequência das festas religiosas. Sobressaíam principalmente as procissões pelo grande luxo, pelo número de figuras simbólicas, por um certo aparato teatral e jogralesco. No extremo Goiás, em Traíras, Pohl assistiu a uma festa de Santa Efigênia, padroeira dos negros, feita com todas estas visualidades: imperador, imperatriz, tiros de roqueira, dutos aos imperantes, cavalhadas, lanças, leilão, etc.

O mineiro e o paulista diferiam bastante de aspecto.

$\mathrm{O}$ mineiro em geral é esbelto e magro, de peito estreito, pescoço comprido, rosto um tanto alongado, olhos negros e vivos, cabelo preto na cabeça e no peito; tem por natureza um nobre orgulho e no exterior um modo brando, afável e inteligente, é sóbrio e parece gostar de uma vida cavalheiresca, assegura Martius. Em todas estas feições assemelha-se mais ao árdego pernambucano que ao paulista pesadão... Seu vestuário nacional difere do paulista. Em geral usa jaqueta curta, de algodão ou de manchéster preto, colete branco de botões de ouro, calça de veludo ou de manchéster, longas botas de couro branco, presas acima do joelho por fivelas; um chapéu de feltro de abas largas abriga-o do sol; a espada e não raro a espingarda são com o guarda-chuva seus companheiros inseparáveis, desde que sai de casa. As viagens, mesmo as mais breves, são feitas em mulas. Os estribos e as rédeas são de prata e do mesmo metal o cabo do facão que enfia na bota abaixo do joelho. Nestas jornadas as mulheres são carregadas em liteiras por negros ou bestas, ou sentam-se, vestidas de longa montaria azul com chapéu redondo, em uma cadeirinha presa à mula.

A pequena estatura do paulista, o cabelo corrido, a face pálida, os olhinhos penetrantes revelavam a procedência americana, no entender de Eschwege, que acrescenta em desacordo com Martius: 
Sua coragem, sua impavidez no perigo, sua agilidade e espírito de iniciativa, sua repugnância a canseiras, sua sede de vingança, patenteiam a procedência selvagem pelo lado materno, assim como sua finura e a vivacidade de seu espírito denunciam a ascendência portuguesa pelo lado paterno.

De resto, chamando pesadão ao paulista, Martius parece referir-se apenas ao aspecto físico, pois antes escrevera:

O paulista goza em todo o Brasil da fama de grande franqueza, impavidez e amor romanesco às aventuras e perigos. Associa a isto um temperamento apaixonado, que o leva à cólera e à vingança, e seu orgulho e inflexibilidade são temidos pelos vizinhos... Muitos paulistas se conservaram sem mescla com os índios; os mamelucos, conforme os graus da mescla, têm a pele quase cor de café, amarela ou quase branca. Traem a mistura indiana antes de tudo a cara larga, com maçãs salientes, olhos pretos e não grandes e certa incerteza de olhar. A estatura elevada e ao mesmo tempo larga, feições fortes, sentimento de liberdade e desassombro, olhos brunos, ou raramente azuis, cheios de fogo e afoiteza, cabelo cheio, preto e liso, musculatura reforçada, decisão e rapidez no movimentos são, aliás, os principais característicos na fisionomia dos paulistas. Em geral pode-se atribuir-lhes um caráter melancólico, misturado com alguma coisa de colérico... Em parte alguma do Brasil há tantos coléricos e histéricos como aqui.

Escreve ainda o mesmo viajante:

Em S. Paulo, homens e mulheres viajam sempre a cavalo ou em mulas; muitas vezes o homem leva uma mulher na garupa. Os cavaleiros usam de um chapéu de feltro pardo de abas largas, um poncho azul, comprido e muito largo, em cujo meio há uma abertura para a cabeça; jaqueta e calças de algodão escuro, botas compridas por tingir, apertadas no joelho por uma correia e um fivelão; uma longa faca de cabo de prata, metida na bota ou presa à cinta, serve para a comida e outros misteres. As mulheres usam longos sobretudos e chapéus redondos. Segundo um provérbio corrente eram dignos de apreço na Bahia eles não elas, em Pernambuco elas não eles, em S. Paulo elas e elas. Não raro ouve-se dizer nesta província: se não fôssemos os primeiros que descobriram as minas de ouro, seríamos ainda beneméritos da pátria graças à canjica e à rede, que primeiros imitamos dos índios.
A canjica paulista, preparada pelo monjolo, preguiça ou negro velho, dominava nos lugares de águas correntes, que dispensavam os pilões: nos sertões do Norte, onde tal abundância de água não era comum, o mungusá que lhe corresponde só se usava nas casas grandes, com escravos para a pilação.

Aos paulistas atribui Martius a descoberta das propriedades medicinais das plantas indígenas, que não podiam ter aprendido com os índios. Desde Pindamonhangaba notavam-se papudos, e em geral os paulistas levaram o papo aos lugares onde foram.

Muitas vezes o pescoço é todo ocupado pela grande intumescência; entretanto, parecem considerar esta disformidade como beleza particular, pois não raro veem-se mulheres com enorme papeira à mostra, ornada de ouros e pratas, sentadas em frente as suas casas, de cachimbo no queixo ou fiando algodão.

No princípio do século, começavam a despertar da hibernação devida às minas e aos grandes êxodos por elas provocados em S. Paulo. A agricultura aos poucos se reanimava; existiam engenhos de açúcar e de aguardente; duvidava-se ainda que o clima permitisse a grande cultura do algodão e do café. A mais importante fonte de receita consistia no comércio de trânsito, de Mato Grosso, de Goiás, de parte de Minas e dos sertões do Sul. Já funcionava a famosa feira anual de Sorocaba.

Um paulista sem vivacidade poderia se chamar o goiano, ainda notável pela aversão à vida de casado.

Segundo uma estatística de 1804, extratada na obra de Pohl, existiam 7.273 brancos, 15.585 mulatos, 7.992 pretos, 19.285 escravos, ao todo 50.135 habitantes. Descontando das 24.371 pessoas do sexo feminino 7.868 escravas, sobre as quais não apresenta informações, havia casadas 809 brancas, 1.668 mulatas, 575 pretas, ao todo 3.052, e solteiras 2.663 brancas, 6.639 mulatas, 4.179 pretas, ao todo 13.481 . Por esta sinopse vê-se também como o elemento africano era numeroso.

A gente de Cuiabá tinha certa semelhança com os mineiros no aspecto; dormitava, porém, nela um gênio sanguinário, talvez aprendido com os Guaicurus, que se revelou estrepitosamente na era regencial, e com mais frequência se tem manifestado depois de proclamada a república. A gente do Paraguai e Guaporé era fraca e doentia. 
Nos campos gerais do Paraná viviam bastantes criadores, mas a verdadeira zona pastoril do Sul ostentava-se nas terras rio-grandenses.

Exceto as faldas da serra geral ainda desertas, capões salteados e alguns trechos ribeirinhos, o território era ocupado por pastagens suculentas, tão propícias à propagação de bois como de cavalos, que dispensavam rações de sal. Abundava a água perene; nunca passavam anos sem chuva; não havia as enredadas catingas de outras regiões menos favorecidas. A proporção entre o gado cavalar e vacum era muito maior do que ao Norte: basta dizer que havia lotes de baguais, cavalos bravios e sem dono; os donos só conheciam os cavalos pela marca, e matavam éguas para extrair o couro. Para viagens mais longas não chegava uma cavalgadura; era preciso levar uma cavalhada.

Como difere isto dos sertões nortistas, com poucos cavalos, todos bem conhecidos e estudados, e o cavalo da sela, ensinado no passo, na estrada, na baralha, no esquipado, e várias outras marchas de que há mestres habilidosos, promovido quase a parente da família!

Quando começou o povoamento já pululava esta criação, procedente das destruídas missões jesuíticas; apossava-se cada um do que lhe convinha, e o uso da bola e do laço, conhecido dos Charruas, dispensava as corridas violentas pelo mato do sertão baiano-pernambucano. $\mathrm{O}$ valor do gado era até certo ponto negativo; sobejava para a população e não havia para onde exportá-lo; consumi-lo sem parcimônia parecia ato de prudência, pois mais facilmente se amansava e os pastos não se esgotariam; os trabalhos de rodeio, únicos reclamados quando a situação se regularizou, eram antes um divertimento que uma canseira.

Toda a guerra era contra as vitelas, informa Aires de Casal, e de ordinário uma não chegava para o jantar de dois camaradas, porque acontecendo quererem ambos a língua, tinham por mais acertado matar segunda do que repartir a da primeira. Havia homem que matava uma rês pela manhã para lhe comer o rim assado; e para não ter o incômodo de carregar uma posta de carne para jantar, onde quer que pousava fazia o mesmo àquela que melhor lhe enchia o olho. Não havia banquete em que não aparecesse um prato de vitelinha recém-nascida.

Aos poucos, a gente se desacostumou do sal, da farinha (comer do arremesso no Pará) e de qualquer conduto. A escassez de lenha obrigava a comer a carne quase crua, apenas sapecada no lume produzido por dejeções animais ou gravetos, e comida quase sempre sem mastigar. Ao mate, beberagem primeiro descoberta nos sertões de Guairá e depois propagada pelos jesuítas, atribui-se a atenuação dos males que deviam resultar desta dieta.

A superfície ligeiramente ondulada, o descampado quase onipresente, a facilidade de alimentação, a abundância de cavalgaduras convidavam à locomoção. Viajava-se principalmente no verão, quando raras vezes chovia, os rios levavam pouca água e aumentava o número de vaus; a importância destes em capitania onde não havia pontes manifesta-se nos passos sem conta que a cada instante se encontram designando localidades. Serviam-se às vezes de pelotas, canoas frágeis feitas de pele. De passagem fique notado que também aqui houve uma época do couro.

Dormia-se ao relento: os aperos do animal serviam de leito. Estendiam por terra grande peça chamada carona, o lombilho substituía o travesseiro, sobre a carona punham o pelego e por cima de tudo deitavam-se embrulhados no poncho e de cabeça descoberta.

Avigorou-se a tendência ao nomadismo com a circunstância de passar por ali a fronteira, uma fronteira disputadíssima, que qualquer dos confinantes ambicionava estender, e de entre ambos meterem-se os campos neutrais, em que nenhum tinha direito de penetrar, por isso mesmo violados a cada instante, máxime da parte do Rio Grande. Os combates regulares não subiram a muitos, mas as surpresas, as arreatas, os encontros singulares, as incursões de contrabandistas constituíam fato quotidiano. Forçosamente os rio-grandenses tornaram-se aventureiros e soldados; só por militares tinham atenção; a Saint-Hilaire deram o título de coronel. A quem não montava bem ou não sabia laçar de cavalo xingavam de baiano ou maturango.

Este desbarato semibárbaro modificou-se graças ao aumento da população em parte, em parte graças às secas do Norte. O Ceará não pode mais fornecer a carne a que acostumara parte da gente do litoral e experimentou-se o charque do Rio Grande; diz-se que cearenses concorreram para a fundação de S. Francisco de Paula, mais tarde Pelotas. Abriu-se assim uma fonte de riqueza, o gado cresceu de valor e as estâncias, também aqui estabelecidas geralmente nas eminências, começaram a ter alguma organização. Com as charqueadas foram introduzidos os negros, 
que chegaram a muitas dezenas de mil. Algumas estâncias rendiam milhares de cruzados, esbanjados no jogo e nas apostas.

$\mathrm{Na}$ Bahia, por 1803, cerca de quarenta navios, de duzentas e cinquenta toneladas cada um, empregavam-se no comércio do charque do Rio Grande, que mal completavam a viagem dentro de dois anos. Levavam da Bahia aguardente, açúcar, louça, mercadorias europeias, principalmente inglesas e alemãs, que passavam por prata de contrabando em Maldonado e Montevidéu. Durante este tempo as tripulações empregavam-se em carregar couro e carne seca. Os navios chegando à Bahia vendiam o charque e retalho, a dois vinténs a libra. Dispondo da carga por este modo em vez de desembarcá-la, detinham-se no porto cinco meses e até mais, de modo que, observa Lindley, no tempo consumido por uma só viagem podiam ser feitas três.

A agricultura nunca ficou de todo descurada. A produção do trigo atingiu a milhares de alqueires; cultivaram outros cereais, a própria mandioca. Aos inconvenientes da proximidade do gado solto obviava-se abrindo valados, fazendo sebes vivas de sabugueiro e cactos, levantando cercas de cabeças com chifres. Entretanto, a faixa agrícola ocupava uma área insignificante, que só se dilatou depois da chegada de imigrantes alemães. A decadência na lavoura do trigo, atribuída a certas medidas antieconômicas tomados pelo governo central e à deterioração das sementes em consequência da ferrugem, deve ter causas mais profundas, pois não foi ainda possível reerguê-la.

Saint-Hilaire, que percorreu a região, pinta-nos o rio-grandense da campanha como vivo, corado, em geral de cor branca, de estatura avantajada, sem curiosidade intelectual, de maneiras agrestes, incrivelmente voraz e pouco sensível, senão cruel... Falando de alvoroço todas as vezes que se carneava alguma rês, repara:

A ideia de em pouco poder se fartar de carne é um dos motivos do prazer, mas não é o único; o maior é matar e vaca e espedaçá-la, independente de toda a esperança de poder satisfazer logo a sua gula. Entretanto, cumpre confessá-lo, esta paixão é uma das que dominam os habitantes da capitania do Rio Grande.

Ao mesmo autor deve-se uma observação que explica uma porção de fatos decorridos desde a regência. Os mineiros, afirma, não se apegam ao seu país. Com efeito, nem um hábito particular ali os retém, e não lhes custa acharem outro melhor. Acresce que a inteligência, que lhes é natural, garante-lhes por toda a parte meios fáceis de subsistirem. Os habitantes desta capitania, ao contrário, nunca saem de sua terra, porque sabem que alhures seriam obrigados a renunciar a andarem sempre a cavalo e em parte alguma achariam carne em tamanha abundância.

$\mathrm{Na}$ formação do rio-grandense entraram sobretudo açorianos, nortistas, principalmente de S. Paulo, e não poucos espanhóis imigrados ou incorporados. Sobretudo na fronteira meridional deu-se a penetração das duas línguas. Havia poucos mulatos. Notava-se a certos respeitos um quê de mocidade fogosa ausente das outras capitanias. O combate contra seres animados difere muito nos efeitos da luta travada contra as massas da vegetação ou contra as inclementes forças cósmicas, como ao Norte.

À beira-mar pobres pescadores arrastavam existência miserável; as armações de baleias davam trabalho durante uma estação apenas e apenas em poucos pontos; a pescaria feita em maior escala, como em Porto Seguro e alhures, não dispensava a importação entre as espécies de maior consumo. O contrabando universalizado zombava de todas as medidas de repressão. Os proprietários rurais, possuindo melhores aviamentos, casas mais espaçosas e mobílias menos sumárias, prosseguiam na lavoura aleatória de drogas de luxo para o estrangeiro, esbanjando as riquezas naturais, indiferentes às culturas dos gêneros de primeira necessidade e à formação de mercados internos. Vítima desta latronicultura, a escravidão africana condenava-a por sua vez à imobilidade e ao recuo. As crises agrícolas repetiam-se; as valorizações disfarçavam sem extinguir o vício congênito.

Os antigos povoados, assentes, como Igaraçu e Porto Calvo, nos limites da cabotagem fluvial, definharam à medida que as embarcações cresceram de calado. A prosperidade mercantil pedia o contacto do oceano. Os centros de maior movimento eram São Luís do Maranhão, Recife, Bahia e Rio.

Nas cidades costeiras o pobre índio sumia-se ante o europeu e o negro com seus descendentes puros ou mesclados. o preconceito de cor agonizava no exclusivismo dos corpos armados, como o dos Henriques, composto só de pretos, nas confrarias, de que algumas só admitiam pretos, pardos ou brancos, na especialização de certos padroeiros, como a Senhora do Rosário, São Benedito, São Gonçalo Garcia. A impedir ou sequer 
minorar a mestiçagem não chegava seu alento; era antes uma tradição meio delida do que uma força viva.

O serviço doméstico tocava aos escravos, sempre em número excessivo, pois vivia-se com pouco, e graças à criação miúda, aos mariscos abundantes, ao peixe barato, aos engenhosos e múltiplos quitutes, grassavam a prodigalidade e a imprevidência da economia naturista. Alguns deles empregavam-se na faina dos transportes por terra e por água; alguns aprendiam ofícios; outros, pagando jornais convencionados com os donos, procuravam ocupações a seu gosto. Conversavam às vezes em língua africana, constituíam grêmios secretos e praticavam feitiçarias. Sua alegria nativa, seu otimismo persistente, sua sensualidade animal sofriam bem o cativeiro.

Nunca ameaçaram a ordem de modo sério, e os carregadores davam certa animação às ruas.

São mandados com cestos vazios e longas varas a procurar emprego em benefícios de seus senhores, escreve John Luccok. Mercadorias pesadas transportam-se ao ombro entre dois parceiros por meio destas varas, às quais se passam umas alças, que levantam o fardo um pouco acima do solo. Se a carga for muito grande para um parelha, forma-se um bando de quatro, de seis e até mais, de que um, em geral o mais inteligente, é escolhido para dirigir o trabalho. Este para promover a regularidade dos esforços, e especialmente uniformizar o passo, entoa sempre um canto africano, de música breve e simples; no fim respondem todos em coro estridente. O coro continua enquanto dura o trabalho, e parece aliviar o peso e alegrar o coração.

Os mulatos, gente indócil, e rixenta, podiam ser contidos a intervalos por atos de prepotência, mas reassumiam logo a rebeldia originária. Suas festas, menos cordiais que as dos negros, não raro terminavam em desaguisados; dentre eles saíam os assassinos e os capangas profissionais. Crescendo em número, desconheceram, e afinal extinguiram as distinções de raça e foram bastantes fortes para romper com as formas do convencionalismo vigente e viver como lhes pedia a índole irrequieta. Para o nivelamento concorreu sobretudo a parte feminina, com seus dengues e requebros lascivos. Spix e Martius ouviram cantar na Bahia:

Uma mulata bonita
Não carece de rezar,

Abasta o mimo que tem

Para sua alma se salvar.

O convencionalismo oprimia a gente branca: funcionários pretensiosos vindos da metrópole e abrangendo no mesmo desdém soberano a terra e os moradores, negociantes grosseiros e pouco lisos nas transações, meros consignatários de seus patrícios, que por sua vez não passavam de consignatários de ingleses, capitalistas desconfiados, descendentes empobrecidos de pais ricos e perdulários, irmãos das almas, os próprios mulatos, quando a multiplicidade dos cruzamentos disfarçava-lhes a casta, em público moviam-se sorumbaticamente, como autômatos.

Toda a população parecia de língua atada, informa ainda Luccock; não havia brinquedo de meninada, vivacidade de rapazes, gritaria ruidosa de gente mais entrada em anos. "O primeiro grito geral que ouvi no Rio foi no aniversário da rainha em 1810. Seguiu-se a um fogo queimado nesta ocasião e foi um viva abafado, não frio, porém tímido; parecia perguntar se podia ser repetido".

De sua residência, no cruzamento da rua do Ouvidor com a da Quitanda, assistia a uma cena, que descreve do seguinte modo:

Precisamente neste lugar, todos os dias não santificados pela manhã, reuniam-se os solicitadores com os meirinhos para tratar de negócios. A generalidade deles usava de velhos casacos pretos surrados, alguns com bastantes remendos, e tão mal adaptados à altura e à forma dos donos, que excitavam a suspeita de não terem sido estes os primeiros que os possuiram; os coletes eram de cores mais alegres, com longos peitos bordados, grandes golas e profundas algibeiras; os calções eram pretos e tão curtos que mal chegavam aos lombos ou aos joelhos, onde se prendiam com fivelas quadradas de diamantes falsos, as meias de algodão fiado em casa e enormes as fivelas dos sapatos. As cabeças eram cobertas de cabeleiras empoadas e punham por cima chapéus de bico, grandes e sebosos, em que usualmente colocavam um tope preto. À esquerda traziam um espadagão muito velho e estragado. Era divertido observar com que cerimônias minuciosas estes cavalheiros e seus subalternos dirigiam-se uns a outros; com que ordem exata se curvavam e tiravam os sujos 
chapéus; com que formas perversas e fria deliberação combinavamse para esvaziar o bolso de seus clientes.

A educação reduzia-se a expungir a vivacidade e a espontaneidade dos pupilos. Meninos e meninas andavam nus em casa até a idade de cinco anos; nos cinco anos seguintes usavam apenas de camisas. Se porém iam à igreja ou a alguma visita, vestiam com todo o rigor da gente grande, com a diferença apenas das dimensões. Poucos aprendiam as ler. Com a raridade dos livros exercitava-se a leitura em manuscritos, o que explica a perda de tantos documentos preciosos.

Só os frades, a exemplo da gente de cor, obedeciam aos ditames do temperamento, sem medo de escândalo e até procurando-o.

Um dos motivos da relaxação é haverem muitos conventos e poucos religiosos, escrevia Fr. Caetano, bispo do Pará; a causa para não poderem satisfazer a todas as observâncias brevemente degenera em pretexto frívolo para se eximirem até das mais fáceis e ei-los aî ociosos, inúteis absolutamente à igreja e ao estado.

A tanto subiu sua desenvoltura que dificilmente encontravam noviços nos últimos tempos. Das freiras e recolhidas não se contavam iguais excessos.

Gozavam de prestígio os padres, os genuínos representantes da mentalidade até o começo do segundo império, quando os substituiram no cenário bacharéis formados pelas academias de S. Paulo e Olinda. As virtudes da sua vocação raros possuíam, mas o caso de tão comum não causava estranheza. Alguns, rompendo com o exclusivismo do latim, aprenderam francês e até inglês, cultivavam as ciências naturais, esposavam as ideias dos enciclopedistas, entusiasmaram-se pelas tragédias da revolução francesa, conheciam as teorias de Adam Smith.

Entre eles contavam-se pedreiros livres, que já existiam em pequeno número, oficiais portugueses e brasileiros viajados no estrangeiro, e não se reuniam ainda em lojas. A população, que aliás não podia conhecê-los, pois ninguém se animava a apregoar-se como tal, votava-lhes um terror louco; circulavam notícias pavorosas de suas abominações sacrílegas, entre elas e a de se aprazerem em apunhalar crucifixos. Apesar de sua exiguidade ou por causa desta, dispunham de certa influência e conseguiram dar escapula ao inglês Thomas Lindley, preso na Bahia por contrabandista.
Os principais divertimentos dos pracianos (citizens) são as festas dos diferentes santos, profissões de freiras, funerais suntuosos, a semana santa, etc., celebrados rotativamente, com grandes cerimônias, músicas e procissões frequentes, informa este viajante. Mal passa um dia em que não ocorra uma ou outra destas festas, e assim se apresenta um círculo de oportunidade para unir a devoção e o prazer, que é vivamente abraçado, em particular pela mulher.

Em grandes ocasiões destas, depois de virem da igreja, visitam-se uns a outros e saboreiam um jantar mais farto que de costume, durante e passado o qual bebem quantidades desmedidas de vinho. Quando alcançam uma temperatura extraordinária introduz-se o violino ou a guitarra, começa o canto, logo seguido da excitante dança negra, mistura de danças da África e dos fandangos de Espanha e Portugal, que consiste em um indivíduo de cada sexo dançar ao toque monótono do instrumento, sempre no mesmo compasso, quase sem mover as pernas, mas com todos os movimentos licenciosos do corpo, juntado-se durante a dança em contacto estranhamente imodesto. Os espectadores, acompanhando a música de um coro improvisado e dando palmas, saboreiam a cena com um gozo indescritível.

As mulheres poucas vezes saíam a público e iam às missas de madrugada; algumas serviam-se de cadeirinhas, carregadas por negros de bela estampa e rica libré; carruagens pode-se dizer não havia. A maior parte do tempo levavam em seus aposentos, quase em mangas de camisas, sem meias e até sem tamancos, ouvindo das mucamas histórias de carochinha ou bisbilhotices frescas, penteando o cabelo, embevecidas nos cafunés. Bordavam, faziam rendas ou doces, cantarolavam modinhas sentimentais, comunicavam com as vizinhas pelos quintais; entretinham-se com quitandeiras e beatas, ou abrigadas por uma rótula discreta procuravam saber o que havia na rua. As moças solteiras engordavam, quando se fazia esperar muito o dia do casamento, felizes as que encontravam "casa de Gonçalo, em que a galinha canta mais que o galo".

Das fluminenses, diz Luccock que seus ornatos produziam um efeito agradável, e molduravam os encantos de uma face redonda, de feições regulares, olhos negros, vivos e curiosos, fronte lisa e aberta, boca expressiva de simplicidade e bom gênio, ocupada por uma fieira de dentes 
brancos e iguais, unidos a um rosto sofrivelmente bonito, um ar risonho e um modo alegre, franco e sem malícias.

Tal, acrescenta, é a aparência comum de uma moça de cerca de treze ou quatorze anos. Aos dezoitos a natureza atingiu a maturidade completa na brasileira. Alguns anos mais tarde torna-se corpulenta e até pesadona; adquire uma grande giba nas espáduas, e anda com um passo desgracioso e cambaleante. Começa a decair, perde o bom humor da fisionomia, e substitui-o por uma carranca; olhar e boca exprimem ambos que se acostumou a exprimir paixões vingativas e violentas, as faces ficam privadas de frescura e de cor, e aos vinte e cinco anos ou trinta transformase numa velha perfeitamente enrugada.

Os homens jogavam, frequentavam cafés, iam às casas de pasto, palestravam sobre assuntos muito limitados, quase sempre vida alheia. Os acontecimentos mais comezinhos deformavam-se em intermináveis comentários maliciosos. Abundavam as alcunhas. Mesmo a morte se desrespeitava. Se morria alguém com fama de santo, se aparecia algum cadáver incorrupto, estabelecia-se um reboliço na população e a procura de relíquias assumia as mais indiscretas formas. Se ao contrário corria que a alma se perdera, corriam logo boatos prodigiosos, assombravam-se as casas e sentia-se a proximidade das trevas exteriores onde há choro e ranger de dentes. Ainda hoje se nota isto no interior.

No Rio, e o mesmo se deveria com pouca diferença notar nas outras cidades marítimas, a maioria das casas era térrea. Na frente havia uma sala assoalhada de bom tamanho; atrás ficavam as alcovas, a cozinha, o quintal. Embaixo dos poucos sobrados existiam geralmente vendas. A família se reunia na varanda no fundo, as mulheres sentadas em esteiras, os homens encostados a qualquer coisa, ou andando de uma parte para outra. Aí jantavam numa mesa velha estendida sobre dois cavaletes, cercada de bancos de pau e às vezes uma ou duas cadeiras. A principal refeição era ao meio-dia, e então o dono, a dona da casa, os filhos sentavam-se todos a roda; mais comumente, porém, acocoravam-se no chão. Os alimentos molhados vinham em terrinas ou cuias; os alimentos secos em cestas; comia-se em pratinhos de Lisboa. Só os homens serviam-se de faca; mulheres e meninos comiam com a mão.

Quando um cavalheiro fazia qualquer visita, se não era íntimo da casa, ia de ponto em branco, chapéu armado, fivela nos sapatos e nos joelhos, espada à cinta, segundo Luccock. Ao chegar batia palmas para chamar a atenção, e soltava um espécie de som sibilante, emitido entre os dentes e a ponta da língua. Acudia uma criada que de modo áspero e tom fanhoso perguntava quem era e ia levar o recado ao patrão. Se o visitante era algum amigo ou não reclamava cerimônias, aparecia logo o dono da casa, levava-o para a sala, protestando alto o prazer com que o recebia, fazendo-lhe discursos cheios de cumprimentos, acompanhado de reverências, e antes de entrar em negócio, se disto se tratava, pedia-lhe muitas desculpas pela sem-cerimônia da recepção. Se o visitante era de cerimônia, uma criada levava-o para a sala, donde ao entrar via muitas pessoas que aí estavam sairem por outra porta. Aqui esperava só, talvez meia hora, até o cavalheiro aparecer numa espécie de trajo de meio rigor. Ambos se inclinam profundamente a distância; depois de haver mostrado suficiente perícia nesta ciência, ganhando tempo para apurar a posição e as pretensões do outro, aproximavam-se, com dignidade e respeito correspondente se desiguais; com familiaridade se supostos proximamente iguais. Tratava-se e despachava-se o negócio sem demora. Pede-se ao estranho que considere a casa como sua, nota Pohl; se mostra agradar-se de qualquer coisa, exige o costume que lhe seja oferecida, pedindo-se que leve aquela insignificância.

As ruas eram estreitas, sem calçamento, sem iluminação ou iluminadas a azeite de peixe. A água e os esgotos ficavam entregues à iniciativa particular. Enterravam-se os cadáveres nas igrejas. Só a pouca população explica a ausência de epidemias. Da higiene pública incumbiamse as águas da chuva, os raios do sol e os diligentes urubus. Constituíam exceção notória o passeio público e o aqueduto do Rio.

Depois de brutalmente extintas as primeiras tentativas industriais, ficaram nas cidades apenas mecânicos que trabalhavam por encomenda e a quem se pagava só o feitio.

Quando um oficial ganhava algumas patacas folgava até acabar de comê-las, observa Saint-Hilaire. Apenas possuía a ferramenta mais necessária, e quase nunca andava provido das matérias que devia feitiar. Assim tinha-se de fornecer couro ao sapateiro, linha ao alfaiate, madeira ao marceneiro; adiantava-se dinheiro para comprarem tais objetos, mas quase sempre gastavam o dinheiro e a obra não se fazia ou se fazia só passado um tempo considerável. Quem tinha alguma coisa a encomendar precisava de fazê-lo com 
larga antecedência. Suponhamos por exemplo que fosse uma obra de marcenaria, era necessário primeiro empregar amigos para arranjarem no campo a madeira precisa; tinha-se depois de mandar cem vezes à casa do oficial, ameaçá-lo, e às vezes em definitivo nada conseguir. Perguntava a um homem honrado de S. Paulo como fazia quando precisava de um par de sapatos. Encomendo-o, disse-me, a vários sapateiros ao mesmo tempo e entre eles acha-se ordinariamente um que, premido pela falta de dinheiro, se resigna a fazê-lo.

Os oficiais do Rio tinham a pretensão de possuir grandes segredos, mas ignoravam as coisas mais simples, narra Luccock. Tendo perdido uma chave, foi à procura e afinal encontrou um operário que o tirasse do aperto.

Deteve-me longo tempo, mas em compensação apareceu-me de ponto em branco, chapéu armado, de fivelas nos sapatos e nos joelhos e correspondentes parafernais. À saída remanchou ainda à espera de algum negro que lhe carregasse o martelo, o escopro e outro instrumento pequeno. Sugeri-lhe que eram leves, e propus eu próprio carregar parte ou todos; mas isto teria sido solecismo prático tamanho como usar ele das próprias mãos. O cavalheiro esperou pacientemente até aparecer um negro, fez então seu trato e marchou com a devida solenidade acompanhado de seu servo temporário. Despachou-se depressa, arrombando a fechadura em vez de arrancála; então o figurão, fazendo-me uma profunda mesura, partiu com seu acólito.

Os mecânicos nunca formaram grêmios profissionais à maneira da Europa: eram para isso muito poucos, e se nas cidades podiam viver de um só ofício, em lugares de população menos densa precisavam de sete instrumentos para ganhar a subsistência. Mesmo nas cidades faziam-lhes concorrência os oficiais escravos.

A falta de grêmios notava-se nas outras classes. Continuavam as históricas pessoas morais, mas sua ação, já enfraquecida pela vastidão do território, acabara de definhar desde que o absolutismo nivelador desatendeu a seus privilégios. Se excetuarmos algumas irmandades e associações de beneficência como as casas de misericórdia, sempre beneméritas e sempre vivazes, as manifestações coletivas eram sempre passageiras: mutirão, pescarias, vaquejadas, feiras, novenas. Entre o estado e a família não se interpunham coordenadores de energia, formadores de tradição, e não havia progressos definitivos. Um indivíduo podia tentar uma empresa e levá-la a bom êxito; com a sua ausência ou com a sua morte perdia-se todo o trabalho, até vir outro continuá-lo passados anos, para afinal colher o mesmo resultado efêmero.

Vida social não existia, porque não havia sociedade; questões públicas tão pouco interessavam e mesmo não se conheciam: quando muito sabem se há paz ou guerra, assegura Lindley. É mesmo duvidoso se sentiam, não uma consciência nacional, mas ao menos capitanial, embora usassem tratar-se de patrício e paisano. Um ou outro leitor de livro estrangeiro podia falar na possibilidade da independência futura, principalmente depois de fundada a república dos Estados Unidos da América do Norte e divulgada a fraqueza lastimável de Portugal.

Não se inquiria, porém, o meio de conseguir tal independência vagamente conhecida, tão avessa a índole do povo a questões práticas e concretas. Preferiam divagar sobre o que se faria depois de conquistá-la por um modo qualquer, por uma série de sucessos imprevistos, como afinal sucedeu. Sempre a mesma mandriice intelectual de Bequimão e dos Mascates!

Cinco grupos etnográficos, ligados pela comunidade ativa da língua e passiva da religião, moldados pelas condições ambientes de cinco regiões diversas, tendo pelas riquezas naturais da terra um entusiasmo estrepitoso, sentindo pelo português aversão ou desprezo, não se prezando, porém, uns aos outros de modo particular - eis em suma ao que se reduziu a obra de três séculos. 